\title{
Prevalence and Risk Factors of Metabolic-Associated Fatty Liver Disease in School-Age Children and Adolescents in Shenyang, China
}

\author{
Guan Lin \\ China Medical University First Hospital \\ Zhang Xinhe \\ China Medical University First Hospital \\ Tian Haoyu \\ China Medical University First Hospital \\ Jin Xing \\ China Medical University First Hospital \\ Li Dan \\ China Medical University First Hospital \\ Wang Ningning \\ China Medical University Fiirst Hospital \\ Sun Jing \\ China Medical University First Hospital

\section{Xue Wang} \\ China Medical University First Hospital \\ Zeng Zilu \\ China Medical University First Hospital \\ Yiling Li ( $\nabla$ lyl-72@163.com) \\ China Medical University First Hospital
}

\section{Research article}

Keywords: MAFLD, Children, Adolescent, Epidemiology, Questionnaire

Posted Date: September 15th, 2020

DOl: https://doi.org/10.21203/rs.3.rs-70922/v1

License: (1) This work is licensed under a Creative Commons Attribution 4.0 International License. Read Full License 


\section{Abstract}

Background: Metabolic-associated fatty liver disease (MAFLD) refers to abnormal accumulation of fat in the liver for metabolic dysfunction. With modern socioeconomic conditions and changes in dietary patterns, the prevalence of MAFLD is increasing, to the detrimental of children's learning and quality of life. We investigated the prevalence and influencing factors of metabolic-associated fatty liver disease (MAFLD) in schoolaged children and adolescents in Shenyang, China.

Methods: In 2019, we collected demographic, anthropometric and liver health assessments from a random sample of Shenyang' s school-aged children (7-12 years old) and adolescents (13-18 years old). Experienced hepatologists used transient elastography to diagnose the presence of fatty liver in the students. A random subsample was selected to complete a questionnaire to explore the impact of lifestyle habits on fatty liver disease.

Results: The overall prevalence of MAFLD in these students was $23.83 \%$, with a non-significant difference between children (22.73\%) and adolescents (24.43\%). The prevalence of MAFLD was significantly higher among boys than among girls. Compared with non-overweight students, a significantly higher proportion of the overweight group had fatty liver. Moreover, questionnaire responses on exercise habits, normal diet, and parental factors were associated with fatty liver.

Conclusions: MAFLD is very prevalent in children and adolescents in Shenyang city. Due to the close relationship between MAFLD and obesity, lifestyle plays a major role in the occurrence of MAFLD.

Trial registration: the First Affiliated Hospital of China Medical University, [2020]2020-258-2. Registered 6 June 2020 - Retrospectively registered.

\section{Background}

1. Nonalcoholic fatty liver disease (NAFLD) refers to the abnormal accumulation of fat in the liver for reasons other than alcohol consumption. It is the most common chronic liver disease among children and adolescents ${ }^{[1]}$. Main risk factors for NAFLD include obesity, hyperlipidemia, hypertension, and insulin resistance ${ }^{[2]}$; common clinical manifestations include irritability, fatigue, muscle soreness, cramps, and headache ${ }^{[3]}$. However, most children and adolescents with NAFLD do not show symptoms. Uncontrolled nonalcoholic fatty liver can develop further into nonalcoholic steatohepatitis (NASH), liver fibrosis, cirrhosis, and even liver cancer ${ }^{[4]}$. Furthermore, NAFLD is related to many extrahepatic diseases, increasing the risk of type 2 diabetes and atherosclerosis in children and adolescents and, in some cases, affecting the structure of the left ventricle of the heart and the systolic and diastolic function ${ }^{[5]}$. NAFLD has also been correlated with changes in intestinal flora, obstructive sleep, apnea, and polycystic ovary syndrome ${ }^{[6]}$. Liver biopsy is the gold standard for the diagnosis of NAFLD ${ }^{[7]}$, but as an invasive practice, it is rarely used for children. At present, the most universal test is liver ultrasound. The most effective treatment method for NAFLD in children and adolescents is weight loss. Drug treatment options are relatively limited but have recently shown great promise for future use. Moreover, vitamin E has been shown to improve the histology of NASH in children and adolescents ${ }^{[8]}$ and may have a similar effect in NAFLD.

2. The latest consensus proposal by International Fatty Liver Naming Group redefined NAFLD to metabolic-associated fatty liver disease (MAFLD). The diagnosis was modified to be based on metabolic dysfunction (obesity, hyperglycemia, hypertension, dyslipidemia, etc.) and no longer based on alcohol intake. The definition of MAFLD also covers other liver diseases ${ }^{[9]}$.

3. School age is a critical period of growth and development, and physical health at this stage is particularly important and is the basis for a normal learning life. However, with modern socioeconomic conditions and changes in dietary patterns, the prevalence of MAFLD is increasing, to the detrimental of children' s learning and quality of life. However, there is little published information on MAFLD in school-aged children and adolescents. Therefore, this novel study aimed to determine the prevalence of MAFLD in Shenyang. This study investigated factors associated with the occurrence of MAFLD and to provide new ideas for the diagnosis and treatment of MAFLD in school-aged children and adolescents.

\section{Methods}

\section{Study data}

This study was conducted in Shenyang, the capital of the northeastern Chinese province of Liaoning. Data were collected during November and December of 2019 as a retrospective cohort study. We used stratified random sampling to first select two districts, then an elementary school, a middle school, and a high school in each district. Finally, two classes were randomly selected at each grade level of the selected school. All students aged between 7 to 18 years old and had been living in Shenyang for a period of 5 years or more. At last, 1309 students were conducted physical examination. The following students were excluded: (1) Those who were allergic to the couplant; (2) Those who did not cooperate examination; (3) Thoses who had incomplete datawere. After the exclusion, 1,301 children and adolescents were included in the study, accounting 
for $1.58 \%$ of Shenyang's total student population. The study was approved by the First Affiliated Hospital of China Medical University ([2020]2020-258-2).

\section{Anthropometric measurement}

We recorded grade, education, gender, and age from school record systems. Height, weight, waist circumference, and hip circumference were measured in the morning; students had been requested to fast the previous day until after the measurements. Body mass index (BMI) was calculated by weight $(\mathrm{kg})$ divided by the square of height $\left(\mathrm{m}^{2}\right)$. We defined normal weight as a BMI less than 24.0, overweight as a BMI of 24.0 to 27.9, and obesity as a BMI of 28.0 or higher. Waist-to-hip ratio (WHR) was calculated using waist circumference (cm) divided by hip circumference (cm). A WHR $\geq 0.9$ (boys) or $\geq 0.85$ (girls) was defined as abdominal obesity.

\section{Fatty liver examination}

Fatty liver examination was performed by two experienced hepatologists, using transient elastography (Fibroscan). Fibroscan is newly noninvasive device for liver examination. The detection is fast and accurate, especially in the detection of fatty liver. It can not only provide quantitative results of fat but also display information on liver stiffness. Based on manufacturer' s recommendations, the diagnosis of fatty liver was made according to the value of the resulting according to the controlled attenuation parameter (CAP) value ${ }^{[10]}$. CAP values were categorized as non-MAFLD (CAP value $<238 \mathrm{~dB} / \mathrm{m}$ ), mild fatty liver (238 dB/m $\leq$ CAP value $<259 \mathrm{~dB} / \mathrm{m}$ ), moderate fatty liver (259 dB/m $\leq \mathrm{CAP}$ value $<292 \mathrm{~dB}$ $/ \mathrm{m})$, and severe fatty liver (CAP value $\geq 292 \mathrm{~dB} / \mathrm{m}$ ).

\section{Questionnaire}

We randomly selected three classes from one elementary school, one middle school, and one high school from among the study schools; their parents completed lifestyle questionnaires created by the First Affiliated Hospital of China Medical University, with specific versions for students and parents. The questionnaire included basic information on the respondent's date of birth, physical activity levels, entertainment practices, diet, and learning condition. Parents were also asked about their opinions about MAFLD. The participants were divided into the fatty liver group and the non-fatty liver group according to the FAP results. The relationship between fatty liver disease and living habits was compared in children (712 years) and adolescents (13-18 years).

\section{Statistical analysis}

Students' results were analyzed by age, gender, grade level, overweight, obesity, and MAFLD. Age was generally used as a dichotomous variablechildren (7-12 years) and adolescents (13-18 years). Data for continuous variables are reported as the mean \pm standard deviation and compared between groups using Student's t-test. Data for categorical variables are expressed as percentages (\%) or proportions and compared between groups using chi-square tests. The level of significance was set at $p<0.05$. According to the difference of univariate analysis, it will be included in multivariate logistic regressionAll analyses were performed using SPSS software (IBM SPSS Statistics for Windows, Version 23.0. IBM Corp., Armonk, NY, USA).

\section{Results}

\section{Basic information}

The flow of the subjects was seen in Table 1. The average age of participants was $13.31 \pm 2.98$ years old (Table 2 ). A total of 310 students were diagnosed with MAFLD, for a prevalence of $23.83 \%$. Looking separately by age group, $22.7 \%$ of children and $24.43 \%$ of the adolescents were diagnosed with MAFLD.

\section{Risk factors for MAFLD}

Results of the bivariate analyses showed no significant differences between the MAFLD groups in terms of age. However, in both age groups and the combined sample, anthropometric measures were significantly higher in the MAFLD group than in the non-MAFLD group ( $\mathrm{p}<0.001 \mathrm{for}$ all comparisons). Logistic regression analyses revealed height, weight, BMI, waist circumference, and hip circumference as significant risk factors for MAFLD in children and adolescents; results for age and learning stage were not significant. However, liver stiffness in the MAFLD group was significantly higher $(p<0.001)$ than that in the non-MAFLD group; this result was found for adolescents and the combined sample but was not found for children (Tables 3 and 4).

\section{BMI and Fatty liver}

A total of 345 students of the 1,301 study subjects were overweight (BMI $\geq 24) ; 224$ of the overweight students had varying degrees of fatty liver. The overall prevalence rate was $64.93 \%$ (95\% Cl: 0.599-0.700); $9.00 \%$ (95\% Cl: $0.072-0.108)$ of the non-overweight (BMl<24) students had MAFLD $(\mathrm{p}<0.001)$. In addition, the chi-square tests showed that the overweight group had a significantly higher prevalence of mild to moderate severe 
fatty liver than the non-overweight group. The overweight group also had significantly higher values of age, height, weight, waist and hip circumference, WHR, FAP, and liver stiffness ( $\mathrm{p}<0.001)$. There were 203 boys and 142 girls among the overweight students, with prevalence rates of $68.97 \%$ (95\% Cl: $0.625-0.754)$ and $59.15 \%$ (95\% Cl: 0.510-0.673), respectively; these differences were not significant $(p<0.001)$.

The prevalence of fatty liver among obese students was quite high-90.54\% (134 of the 148 students, 95\% Cl: 0.858-0.953). Among them, the proportions of boys and girls with fatty liver were $93.33 \%$ (95\% Cl: $0.881-0.986)$ and $86.21 \%(95 \% \mathrm{Cl}$ : 0.771-0.954), respectively. These prevalence was not significantly different ( $p>0.05$ ) (Table 5 ). The prevalence of overweight, obesity, and abdominal obesity was significantly higher in the MAFLD group ( $p<0.001$ for all comparisons) (Table 3 ). After stratification by sex and age, the prevalence of MAFLD in both boys and girls increased with BMl; this pattern was seen for both age groups (Figure 1).

\section{Grade level and MAFLD}

There were 395 elementary school students, 427 middle school students, and 479 high school students in the study, among whom 91 , 107, and 112 , respectively, were diagnosed with fatty liver. The overall prevalence rate was $23.8 \%$, with grade-level results of $23.04 \%$ (95\% Cl: $0.189-0.272$ ), 25.06\% (95\% Cl: 0.209-0.292), and 23.38\% (95\% Cl: 0.196-0.272), respectively. These differences were not statistically significant (p>0.05). Most of the elementary school students with fatty liver had a mild level, accounting for $15.19 \%$ of their cases. The proportion of junior high school students with moderate fatty liver was the highest. Nonetheless, there was no significant difference in the prevalence of moderate fatty liver among the three grades $(p=0.023)$. The prevalence of severe fatty liver increased significantly with educational level ( $<<0.001)$. There were no significant differences between junior and senior high school students in FAP or liver stiffness. However, both groups were significantly higher on these measures than were the elementary school students $(p<0.001)$. In addition, the value of other anthropometric factors and clinical measurements increased significantly with improvement of academic level ( $p<0.001$ for all comparisons) (Table 6).

\section{Sex and MAFLD}

The 1,301 study subjects included 625 boys and 676 girls. Among the boys, 182 were diagnosed with fatty liver (29.12\%; $95 \%$ Cl: $0.255-0.327$ ); the 128 girls with fatty liver represented a prevalence of $18.9 \%$ (95\% Cl: $0.160-0.219)$. The overall prevalence for boys was significantly higher than that of girls $(p<0.001)$, which mainly reflected the differing prevalence of severe fatty liver. There was no significant difference in age between the two groups. However, the values of height, weight, BMI, waist circumference, hip circumference, WHR, FAP ( $p<0.001 \mathrm{for}$ all comparisons), and liver stiffness ( $<<0.01$ ) were significantly higher in boys (Table 7). The overall prevalence of fatty liver increased with age; for instance, the prevalence of fatty liver in students younger than 8 years old was $2.38 \%$, while the prevalence in students older than 17 years old was $24.76 \%$. After stratification by sex and age, only the 13-14 age group showed a significantly higher prevalence among boys than among girls $(p<0.001)$. Similarly, after stratification by gender and education, the prevalence of fatty liver in the elementary and middle schools, but not high schools, was significantly higher in boys than in girls $(p<0.05)$ (Table 8$)$.

\section{Questionnaire}

The questionnaire was valid for 117 of the 123 students. Tables 9 and 10 present the comparisons of the questionnaire factors between students with and without fatty liver. The basic information of children is consistent with that shown in the epidemiological survey. Fathers of children in the MAFLD group were more likely to have an educational level of high school or lower $(p<0.05)$. Regarding exercise habits, the proportion of students in the MAFLD group who did not exercise or who had poor grade was significantly higher. In terms of eating habits, the students in the MAFLD group ate breakfast less frequently than those in the non-MAFLD group $(p<0.05)$ but had a higher frequency of consuming fast food and snacks ( $\mathrm{p}$ <.05). Furthermore, the ratio of eating carefully and slowly was higher in the non-MAFLD group. Parents of adolescents with MAFLD also had higher BMI. Similar to children, more students ate breakfast every day in non-MAFLD group $(p<0.05)$. Parents of adolescents with MAFLD had less knowledge of nutrition and health. Finally, no significant differences were found between the two groups in basic conditions of birth, recreation, and learning ( $p>0.05)$.

\section{Discussion}

1. Many studies have investigated the prevalence of MAFLD. Jeffery conducted a retrospective survey of 742 children aged $2-19$ years from 1993 to 2003 , reporting an average prevalence of fatty liver of $9.6 \%{ }^{[11]}$. A 15 -year meta-analysis showed an average prevalence of $7.6 \%$ for fatty liver in children and adolescents (ages 1-19 years) ${ }^{[7]}$. The prevalence of fatty liver appears to differ, however, across global populations, including Asia (10.2\%) ${ }^{[9]}$ and Europe $(2.5 \%)^{[12]}$. Jain (2019) also demonstrated this point in a recent dissertation ${ }^{[13]}$, and different countries also have different prevalence rates; for example, in Haryana, India, $22.4 \%$ of children aged $5-10$ years had fatty liver ${ }^{[14]}$. The average prevalence of fatty liver in Chinese children has been estimated at $9.03 \%{ }^{[15]}$. Our study was designed to produce results that are representative for children and adolescents in the city of Shenyang; the prevalence of $23.83 \%$ is high. This phenomenon maybe related to diet and lifestyle, with many children and adolescents in the area preferring sweets and diets heavy in meat. In addition, the weather in the area is generally cold, causing children and adolescents to spend more time indoors with limited opportunity for exercise. 
2. Among overweight children, our estimate of $64.9 \%$ of is significantly higher than the prevalence in non-overweight children. A study conducted in Beijing, China, found that 174 of 387 obese children and adolescents had non-alcohol fatty liver (NAFLD), with a prevalence of $45.0 \%{ }^{[16]}$. An earlier Chinese study also reported a prevalence of $65.9 \%$ among 308 obese children aged 9-14 ${ }^{[17]}$. These results are supported by those of our study, with the prevalence of fatty liver closely related to overweight, obesity, and abdominal obesity. It has been reported that fatty acids are mainly catabolized in the liver ${ }^{[18]}$. Hepatocytes convert triglycerides formed by fatty acid esterification into very low-density lipoprotein and release them. Obese children and adolescents have increased levels of fatty acids entering the liver, which, at some point, will exceed the liver's ability to metabolize them. This can cause the deposition of a large number of fat droplets in the liver, creating the likelihood of liver dysfunction and promoting the formation of fatty liver. In addition, free fatty acids also increase the release of inflammatory mediators and insulin resistance ${ }^{[19]}$, increasing the production of intrahepatic fat ${ }^{[20]}$. Among obese people, central obesity (abdominal obesity) mainly reflects the amount of visceral fat, which has more serious consequences for the liver than peripheral obesity has. In our research, non-overweight children and adolescents still had a $9.0 \%$ prevalence of fatty liver. Fatty liver in non-overweight people increases the risk of cardiac metabolic disease and accompanying serious consequences. On one hand, fatty liver may be related to genetic factors, and many genetic variations have been found. Polymorphisms in the PNPLA3 gene can increase liver fat content and the risk of MAFLD and are possibly related to the severity level of MAFLD ${ }^{[21]}$. The TM6SF2, MBOAT7, and GCKR genes all appear to affect the occurrence and development of MAFLD in children and adolescents ${ }^{[22]}$. On the other hand, fatty liver may be related to irregular lifestyles; excessive intake of fructose promotes the formation of MAFLD, although fructose does not necessarily cause obesity [23]. Studies in adults have found that elevated serum uric acid can increase the risk of MAFLD in lean people ${ }^{[24]}$. However, further exploration is needed to determine whether this conclusion is equally applicable to children and adolescents.

3. We found that boys had a higher prevalence of MAFLD than girls; this conclusion is the same as that drawn in most studies. Estrogen plays a major role in preventing the occurrence and progression of fatty liver ${ }^{[25]}$, and through a variety of mechanisms, it can prevent the accumulation of triglycerides in the liver and thus liver fibrosis. In our survey, boys had a higher prevalence in all age groups, with the difference significant for students aged 13 to 14. In China, this age coincides with the average time of menarche, during which the ovaries begin to produce estrogen. Moreover, according to our questionnaire, boys had higher BMI values than girls (Table 11). The proportion of obese boys, especially those with abdominal obesity, was relatively large compared to that of girls. In terms of diet, boys' questionnaire answers revealed a preference for sweet, high-fat, and high-calorie foods, all of which increase body fat content and the metabolic burden on the liver. Surprisingly, we found a significant difference between MAFLD groups on whether breast milk was exclusively consumed in the first four months after birth. It is not clear whether breast milk consumption is related to the high prevalence among boys. However, the earlier addition of complementary foods increases the burden on the digestive system because of imperfect digestive function in newborns.

4. Some studies have reported that MAFLD can aggregate within families. When exploring the relationship between the prevalence of MAFLD and family living habits, we found several links between parental characteristics and fatty liver in their children. In particular, a high parental BMI was associated with an increased risk of fatty liver in children. Part of the reason may be an inherited tendency for obesity. However, parents' high BMl is related to living and eating habits which will largely be shared by their children. Second, students' MAFLD status was related to parental education levels. Parents with a higher level of education may have a relatively deeper understanding or awareness of health and diseases and may also have increased access to health care systems for the prevention and control of their children' $s$ fatty liver and other diseases.

5. For children and adolescents, increasing exercise should be the first prevention target as physical exercise is the most effective method to prevent and treat MAFLD. Physical exercise can reduce the formation of free fatty acids, inhibit insulin resistance, reduce the risk factors for MAFLD, and has even been shown to reverse the condition ${ }^{[26]}$. Our study also found that children with fatty liver appeared to engage in less exercise, which is consistent with the results of the study of adults conducted by Mansour-Ghanaei et al. However, we did not find a relationship between exercise intensity and fatty liver disease ${ }^{[27]}$. It has been reported that aerobic exercise and resistance exercise can reduce steatosis of MAFLD; people with poor cardiopulmonary function are more suited to resistance exercise ${ }^{[28]}$.

6. Moreover, we should pay attention to eating habits and ensure a healthy diet. It is crucial to ingest appropriate types and amounts of fruits and vegetables. Vegetables and fruits contain a large number of vitamins, which have antioxidant properties and can reduce the risk of liver steatosis ${ }^{[29]}$. Children and adolescents must control the frequency of desserts and sweet beverages, as these foods contain a large amount of fructose, which can induce insulin resistance and promote fat deposition in the liver ${ }^{[30]}$. We found that snacks and fried foods are frequently consumed by children with fatty liver. These are high-calorie foods that are difficult to digest and absorb. They will, eventually, be converted into fat stored in various parts of the body, which will increase the burden on the liver. In addition to the points mentioned above, a regular breakfast has a major effect on the prevention of fatty liver. We have found that eating breakfast less frequently increases the risk of fatty liver in children and adolescents. One study have found that skipping breakfast can cause overweight and obesity ${ }^{[31]}$. This may be the reason why these students are prone to fatty liver. Furthermore, chewing as slowly as possible and eating carefully during meals can prevent excessive dietary intake and fat accumulation. At present, the relationship between sleep and MAFLD has not been determined. Some studies suggest that a short sleep time increases the risk of fatty liver, but we did not find a correlation between sleep time and MAFLD. Finally, our research suggests that sharing of information publicly in communities and other places is effective in reducing the probability of fatty liver. 
Widely available information can increase parents' general health knowledge and, specifically, the harms of obesity. Strengthening the popularization of science is likely related to the occurrence of MAFLD in school-aged children and adolescents.

\section{Conclusions}

The prevalence of MAFLD among school-aged children and adolescents aged 7 to 18 in Shenyang, China is higher than the national average. Through questionnaires and direct physiologic measurements, our study found that MAFLD was closely related to lifestyle habits and parental factors. Larger in-depth studies are needed to more thoroughly explore the relationships betwen the prevalence of MAFLD and lifestyle characteristics in Shenyang children and adolescents.

\section{Abbreviations}

MAFLD, metabolic-associated fatty liver disease;

NAFLD, nonalcoholic fatty liver disease;

$\mathrm{NASH}$, nonalcoholic steatohepatitis;

BMI, body mass index;

WHR, waist-to-hip ratio.

\section{Declarations}

Ethics approval and consent to participate: The study was approved by the First Affiliated Hospital of China Medical University ([2020]2020-2582). Parents of all participants agreed to participate in this project by written consent. And written informed consent for participation in the study was obtained from their guardian (all guardian are their parents).

Consent for publication: Not applicable

Availability of data and materials: The datasets generated and/or analysed during the current study are not publicly available because the public data has not obtained the consent of the participants' guardian, but the data acquisition and analysis have obtained the consent of the participants' guardian. But they are available from the corresponding author on reasonable request.

Competing interests: The authors declare that they have no competing interests

Funding: This research did not receive any specific grant from funding agencies in the public, commercial, or not-for-profit sectors.

Authors' contributions: GL and XZ carried out drafting and revising the article, HT and XJ carried out acquisition of data, DL and NW carried out designing the experiment, JS and XW carried out analysis of data, ZZ carried out interpretation of data, YL carried out final approval of the article.All authors read and approved the final manuscript

Acknowledgements: Not applicable

\section{References}

1. Smith SK, Perito ER. Nonalcoholic Liver Disease in Children and Adolescents. Clin Liver Dis. 2018;22:723-733.

2. Özcan HN, Oğuz B, Haliloğlu M, Orhan D, Karçaaltıncaba M. Imaging patterns of fatty liver in pediatric patients. Digan Interv Radiol. 2015;21:355-60.

3. Goyal NP, Schwimmer JB. The Progression and Natural History of Pediatric Nonalcoholic Fatty Liver Disease. Clin Liver Dis. 2016;20:325-38.

4. Nier A, Brandt A, Conzelmann IB, Özel Y, Bergheim I. Non-Alcoholic Fatty Liver Disease in Overweight Children: Role of Fructose Intake and Dietary Pattern. Nutrients. 2018;10.

5. Pacifico L, Chiesa C, Anania C, De Merulis A, Osborn JF, Romaggioli S, et al. Nonalcoholic fatty liver disease and the heart in children and adolescents. World J Gastroenterol. 2014;20:9055-71.

6. Björklund J, Laursen TL, Kazankov K, Thomsen KL, Hamilton-Dutoit S, Stenbøg E, et al. [Non-alcoholic fatty liver disease in children and adolescents]. Ugeskr Laeger. 2017;179.

7. Anderson EL, Howe LD, Jones HE, Higgins JP, Lawlor DA, Fraser A. The Prevalence of Non-Alcoholic Fatty Liver Disease in Children and Adolescents: A Systematic Review and Meta-Analysis. PLdS One. 2015;10. 
8. Conjeevaram Selvakumar PK, Kabbany MN, Alkhouri N. Nonalcoholic Fatty Liver Disease in Children: Not a Small Matter. Paediatr Drugs. 2018;20:315-329.

9. Eslam M, Sanyal AJ, George J. MAFLD: A consensus-driven proposed nomenclature for metabolic associated fatty liver disease. Gastroenterology. 2020.

10. Sasso M, Beaugrand M, de Ledinghen V, Douvin C, Marcellin P, Poupon R, et al. Controlled attenuation parameter (CAP): a novel VCTE guided ultrasonic attenuation measurement for the evaluation of hepatic steatosis: preliminary study and validation in a cohort of patients with chronic liver disease from various causes.Ultrasound Med Biol. 2010;36:1825-35.

11. Schwimmer JB, Deutsch R, Kahen T, Lavine JE, Stanley C, Behling C. Prevalence of Fatty Liver in Children and Adolescents. Pediatrics. 2006;118:1388-93.

12. Lawlor DA, Callaway M, Macdonald-Wallis C, Anderson E, Fraser A, Howe LD, et al. Nonalcoholic fatty liver disease, liver fibrosis, and cardiometabolic risk factors in adolescence: a cross-sectional study of 1874 general population adolescents. J Clin Endocrinol Metab. 2014;99:E410-7.

13. Jain A. Pediatric Fatty Liver Disease. Mo Med. 2019;116:123-128.

14. Das MK, Bhatia V, Sibal A, Gupta A, Gopalan S, Sardana R, et al. Prevalence of Nonalcoholic Fatty Liver Disease in Normal-weight and Overweight Preadolescent Children in Haryana, India. Indian Pediatr. 2017;54:1012-1016.

15. Song P, Yu J, Wang M, Chang X, Wang J, An L. Prevalence and Correlates of Suspected Nonalcoholic Fatty Liver Disease in Chinese Children. Int J Environ Res Public Health. 2017;14.

16. Zhou X, Hou DQ, Duan JL, Sun Y, Cheng H, Zhao XY, et al. [Prevalence of nonalcoholic fatty liver disease and metabolic abnormalities in 387 obese children and adolescents in Beijing, China]. Zhonghua Liu Xing Bing Xue Za Zhi. 2013;34:446-50.

17. Shi HB, Fu JF, Liang L, Wang CL, Zhu JF, Zhou F, et al. [Prevalence of nonalcoholic fatty liver disease and metabolic syndrome in obese children]. Zhonghua Er Ke Za Zhi. 2009;47:114-8.

18. Fabbrini E, Sullivan S, Klein S. Obesity and Nonalcoholic Fatty Liver Disease: Biochemical, Metabolic and Clinical Implications. Hepatology. 2010;51:679-89.

19. Fang YL, Chen H, Wang CL, Liang L. Pathogenesis of non-alcoholic fatty liver disease in children and adolescence: From "two hit theory" to "multiple hit model". World J Gastroenterol. 2018;24:2974-2983.

20. Kitade H, Chen G, Ni Y, Ota T. Nonalcoholic Fatty Liver Disease and Insulin Resistance: New Insights and Potential New Treatments. Nutrients 2017;9:387.

21. Li J, Hua W, Ji C, Rui J, Zhao Y, Xie C, et al. Effect of the patatin-like phospholipase domain containing 3 gene (PNPLA3) I148M polymorphism on the risk and severity of nonalcoholic fatty liver disease and metabolic syndromes: A meta-analysis of paediatric and adolescent individuals. Pediatr Obes. 2020;2.

22. Nobili V, Alisi A, Valenti L, Miele L, Feldstein AE, Alkhouri N. NAFLD in children: new genes, new diagnostic modalities and new drugs. Nat Rev Gastroenterol Hepatol. 2019;16:517-530.

23. Kumar R, Mohan S. Non-alcoholic Fatty Liver Disease in Lean Subjects: Characteristics and Implications. J Clin Transl Hepatol. 2017;5:216223.

24. Zheng X, Gong L, Luo R, Chen H, Peng B, Ren W, et al. Serum uric acid and non-alcoholic fatty liver disease in non-obesity Chinese adults. Lipids Health Dis. 2017;16:202.

25. Ballestri S, Nascimbeni F, Baldelli E, Marrazzo A, Romagnoli D, Lonardo A. NAFLD as a Sexual Dimorphic Disease: Role of Gender and Reproductive Status in the Development and Progression of Nonalcoholic Fatty Liver Disease and Inherent Cardiovascular Risk. Adv Ther. 2017;34:1291-1326.

26. van der Windt DJ, Sud V, Zhang H, Tsung A, Huang H. The Effects of Physical Exercise on Fatty Liver Disease. Gene Expr. 2018;18:89-101.

27. Mansour-Ghanaei R, Mansour-Ghanaei F, Naghipour M, Joukar F. The Lifestyle Characteristics in Non-Alcoholic Fatty Liver Disease in the PERSIAN Guilan Cohort Study. Open Access Maced J Med Sci. 2019;7:3313-3318.

28. Hashida R, Kawaguchi T, Bekki M, Omoto M, Matsuse H, Nago T, et al. Aerobic vs. resistance exercise in non-alcoholic fatty liver disease: A systematic review. J Hepatol. 2017;66:142-152.

29. Jeznach-Steinhagen A, Ostrowska J, Czerwonogrodzka-Senczyna A, Boniecka I, Shahnazaryan U, Kuryłowicz A. Dietary and Pharmacological Treatment of Nonalcoholic Fatty Liver Disease. MEdicina(Kaunas). 2019;55.

30. Ullah R, Rauf N, Nabi G, Ullah H, Shen Y, Zhou YD, et al. Role of Nutrition in the Pathogenesis and Prevention of Non-alcoholic Fatty Liver Disease: Recent Updates. Int J Biol Sci. 2019;15:265-276.

31. Zalewska M, Maciokowska E. Selected nutritional habits of teenagers associated with overweight and obesity. PeerJ. $2017 ; 5$.

\section{Tables}

Page $7 / 18$ 
Table 3

Comparison of related factors between NAFLD and non-NAFLD group in school-age children and adolescents

\begin{tabular}{|c|c|c|c|c|c|c|c|c|c|}
\hline \multirow[b]{3}{*}{$\mathrm{n}$} & \multicolumn{3}{|l|}{ Chidren } & \multicolumn{3}{|c|}{ Adolescents } & \multicolumn{3}{|l|}{ Total } \\
\hline & \multicolumn{3}{|c|}{ non-MAFLD MAFLD $P$ value } & \multicolumn{3}{|c|}{ non-MAFLD MAFLD $P$ value } & \multicolumn{3}{|c|}{ non-MAFLD MAFLD $P$ value } \\
\hline & 357 & 105 & & 634 & 205 & & 991 & 310 & \\
\hline Age(years) & $9.90 \pm 1.76$ & $9.97 \pm 1.83$ & 0.735 & $\begin{array}{l}15.17 \pm \\
1.48\end{array}$ & $15.22 \pm 1.52$ & 0.681 & $13.27 \pm 2.99$ & $13.44 \pm 2.97$ & 0.386 \\
\hline Height(cm) & $\begin{array}{l}141.93 \pm \\
13.43\end{array}$ & $\begin{array}{l}147.64 \pm \\
15.99\end{array}$ & 0.001 & $\begin{array}{l}165.77 \pm \\
8.65\end{array}$ & $\begin{array}{l}169.12 \pm \\
8.27\end{array}$ & $<.001$ & $\begin{array}{l}157.18 \pm \\
15.61\end{array}$ & $\begin{array}{l}161.84 \pm \\
15.32\end{array}$ & $<.001$ \\
\hline Weight(kg) & $\begin{array}{l}36.90 \pm \\
11.79\end{array}$ & $\begin{array}{l}53.72 \pm \\
22.40\end{array}$ & $<0.001$ & $\begin{array}{l}56.98 \pm \\
11.26\end{array}$ & $\begin{array}{l}81.77 \pm \\
17.38\end{array}$ & $<0.001$ & $\begin{array}{l}49.75 \pm \\
14.97\end{array}$ & $\begin{array}{l}72.27 \pm \\
23.35\end{array}$ & $\begin{array}{l}<.001 \\
0.00\end{array}$ \\
\hline $\mathrm{BMI}\left(\mathrm{kg} / \mathrm{m}^{2}\right)$ & $\begin{array}{l}17.89 \pm \\
3.33\end{array}$ & $\begin{array}{l}23.45 \pm \\
6.52\end{array}$ & $\begin{array}{l}< \\
0.001\end{array}$ & $\begin{array}{l}20.65 \pm \\
3.31\end{array}$ & $28.45 \pm 4.49$ & $\begin{array}{l}< \\
0.001\end{array}$ & $19.66 \pm 3.57$ & $26.76 \pm 5.97$ & $<.001$ \\
\hline Waist(cm) & $\begin{array}{l}63.57 \pm \\
10.44\end{array}$ & $\begin{array}{l}76.51 \pm \\
16.17\end{array}$ & $\begin{array}{l}< \\
0.001\end{array}$ & $\begin{array}{l}68.75 \pm \\
8.12\end{array}$ & $\begin{array}{l}86.93 \pm \\
13.32\end{array}$ & $\begin{array}{l}< \\
0.001\end{array}$ & $66.89 \pm 9.35$ & $\begin{array}{l}83.40 \pm \\
15.15\end{array}$ & $<.001$ \\
\hline Hip(cm) & $\begin{array}{l}79.36 \pm \\
9.43\end{array}$ & $\begin{array}{l}89.70 \pm \\
14.85\end{array}$ & $\begin{array}{l}<.001 \\
0 .\end{array}$ & $\begin{array}{l}91.38 \pm \\
8.82\end{array}$ & $\begin{array}{l}104.71 \pm \\
9.24\end{array}$ & $\begin{array}{l}< \\
0.001\end{array}$ & $\begin{array}{l}87.05 \pm \\
10.73\end{array}$ & $\begin{array}{l}99.62 \pm \\
13.46\end{array}$ & $\begin{array}{l}<.001 \\
0.00\end{array}$ \\
\hline WHR & $0.80 \pm 0.08$ & $0.85 \pm 0.07$ & $\begin{array}{l}< \\
0.001\end{array}$ & $0.75 \pm 0.06$ & $0.83 \pm 0.08$ & $\begin{array}{l}< \\
0.001\end{array}$ & $0.77 \pm 0.07$ & $0.83 \pm 0.08$ & $<.001$ \\
\hline $\mathrm{CAP}(\mathrm{dB} / \mathrm{m})$ & $\begin{array}{l}200.717 \pm \\
23.44\end{array}$ & $\begin{array}{l}264.20 \pm \\
22.81\end{array}$ & $\begin{array}{l}<.001 \\
0.00\end{array}$ & $\begin{array}{l}204.36 \pm \\
23.02\end{array}$ & $\begin{array}{l}281.40 \pm \\
28.77\end{array}$ & $\begin{array}{l}< \\
0.001\end{array}$ & $\begin{array}{l}203.05 \pm \\
23.23\end{array}$ & $\begin{array}{l}275.57 \pm \\
28.07\end{array}$ & $\begin{array}{l}<.001 \\
0.00\end{array}$ \\
\hline $\begin{array}{l}\text { Liver } \\
\text { stiffness(kPa) }\end{array}$ & $5.51 \pm 2.47$ & $5.78 \pm 1.83$ & 0.303 & $5.98 \pm 1.48$ & $7.24 \pm 3.45$ & $\begin{array}{l}< \\
0.001\end{array}$ & $5.81 \pm 1.19$ & $6.74 \pm 3.07$ & $<.001$ \\
\hline Overweight(n/\%) & $23 / 6.44 \%$ & $53 / 50.48 \%$ & $<.001$ & $98 / 15.46 \%$ & $171 / 83.41 \%$ & $<.001$ & $121 / 12.21 \%$ & $224 / 72.26 \%$ & $<.001$ \\
\hline Obesity(n/\%) & 0 & $25 / 23.81 \%$ & $<.001$ & $14 / 2.21 \%$ & $109 / 53.17 \%$ & $<.001$ & $14 / 1.41 \%$ & $134 / 43.23 \%$ & $<.001$ \\
\hline $\begin{array}{l}\text { Abdominal } \\
\text { obesity(n/\%) }\end{array}$ & $69 / 19.33 \%$ & $49 / 46.67 \%$ & $\begin{array}{l}< \\
0.001\end{array}$ & $8 / 1.26 \%$ & $45 / 21.95 \%$ & $\begin{array}{l}< \\
0.001\end{array}$ & $77 / 7.77 \%$ & $94 / 30.32 \%$ & $<.001$ \\
\hline BMI, body mass i & r & to-hip ratio. & & & & & & & \\
\hline
\end{tabular}

Table 4

Logistic regression analysis of NAFLD risk factors in school-age children and adolescents

\begin{tabular}{|c|c|c|c|c|c|c|c|c|c|}
\hline & \multicolumn{3}{|l|}{ Chidren } & \multicolumn{3}{|c|}{ Adolescents } & \multicolumn{3}{|l|}{ Total } \\
\hline & $P$ value & OR & $95 \% \mathrm{Cl}$ & $P$ value & OR & $95 \% \mathrm{Cl}$ & $P$ value & OR & $95 \% \mathrm{Cl}$ \\
\hline Gender & 0.019 & 1.691 & $1.090-2.622$ & $<0.001$ & 1.791 & $1.300-2.466$ & $<0.001$ & 1.759 & $1.358-2.2 .78$ \\
\hline Age & 0.735 & 1.022 & $0.903-1.155$ & 0.681 & 1.022 & $0.920-1.137$ & 0.385 & 1.019 & $0.976-1.064$ \\
\hline Height & $<0.001$ & 1.03 & $1.013-1.047$ & $<0.001$ & 1.046 & $1.027-1.066$ & $<0.001$ & 1.021 & $1.012-1.030$ \\
\hline Weight & $<0.001$ & 1.066 & $1.049-1.082$ & $<0.001$ & 1.137 & $1.116-1.158$ & $<0.001$ & 1.073 & $1.063-1.083$ \\
\hline Waist & $<0.001$ & 1.088 & $1.066-1.111$ & $<0.001$ & 1.179 & $1.152-1.208$ & $<0.001$ & 1.132 & $1.115-1.150$ \\
\hline Hip & $<0.001$ & 1.085 & $1.062-1.109$ & $<0.001$ & 1.184 & $1.154-1.215$ & $<0.001$ & 1.107 & $1.091-1.123$ \\
\hline Grade level & 0.099 & 0.882 & $0.468-1.663$ & 0.414 & 1.141 & $0.831-1.567$ & 0.449 & 1.117 & $0.811-1.539$ \\
\hline BMI & $<0.001$ & 1.290 & $1.219-1.366$ & $<0.001$ & 1.608 & $1.503-1.721$ & $<0.001$ & 1.399 & $1.344-1.456$ \\
\hline
\end{tabular}


Table 6

Comparison of prevalence and related factors among elementary school students, middle school students and high school students

\begin{tabular}{|c|c|c|c|c|}
\hline & Primary school students & Middle school students & High school students & $P$ value \\
\hline $\mathrm{n}$ & 395 & 427 & 479 & \\
\hline Prevalence(n/\%) & $91 / 23.04 \%$ & $107 / 25.06 \%$ & $112 / 23.38 \%$ & $>0.05$ \\
\hline Prevalence of mild fatty liver(n/\%) & $60 / 15.19 \%$ & $38 / 8.9 \%$ & $41 / 8.56 \%$ & $<0.001$ \\
\hline Prevalence of moderate fatty liver(n/\%) & $23 / 5.82 \%$ & $45 / 10.54 \%$ & $32 / 6.68 \%$ & 0.023 \\
\hline Prevalence of severe fatty liver(n/\%) & $8 / 2.03 \%$ & $24 / 5.62 \%$ & $39 / 8.14 \%$ & $<0.001$ \\
\hline Age(years) & $9.57 \pm 1.68$ & $13.50 \pm 0.97$ & $16.23 \pm 0.91$ & $<0.001$ \\
\hline Height(cm) & $140.51 \pm 13.37$ & $163.89 \pm 8.67$ & $167.97 \pm 8.36$ & $<0.001$ \\
\hline Weight(kg) & $38.26 \pm 15.74$ & $59.31 \pm 16.55$ & $65.27 \pm 16.27$ & $<0.001$ \\
\hline BMI(kg/m2) & $18.73 \pm 4.83$ & $21.89 \pm 4.96$ & $23.03 \pm 4.94$ & $<0.001$ \\
\hline Waist(cm) & $65.95 \pm 13.13$ & $71.47 \pm 12.61$ & $74.27 \pm 12.19$ & $<0.001$ \\
\hline Hip(cm) & $80.23 \pm 11.55$ & $91.50 \pm 9.87$ & $96.84 \pm 10.43$ & $<0.001$ \\
\hline WHR & $0.82 \pm 0.08$ & $0.78 \pm 0.08$ & $0.76 \pm 0.07$ & $<0.001$ \\
\hline $\mathrm{CAP}(\mathrm{dB} / \mathrm{m})$ & $214.58 \pm 35.34$ & $222.30 \pm 40.52$ & $223.31 \pm 41.14$ & 0.002 \\
\hline Liver stiffness(kPa) & $5.54 \pm 2.48$ & $6.13 \pm 2.56$ & $6.36 \pm 1,70$ & $<0.001$ \\
\hline
\end{tabular}

Table 8

Comparison of prevalence of NAFLD under the delamination of gender, grade level and age

\begin{tabular}{|llllllll|}
\hline Variable & Total(n) & $\mathbf{( \% )}$ & Boys(n) & $\mathbf{( \% )}$ & Girls(n) & (\%) & $P$ value \\
\hline Age(years) & & & & & & & \\
\hline $7-8$ & $22 / 84$ & $2.38 \%$ & $11 / 37$ & $29.73 \%$ & $11 / 47$ & $23.40 \%$ & 0.513 \\
\hline $9-10$ & $38 / 195$ & $19.49 \%$ & $20 / 84$ & $23.81 \%$ & $18 / 111$ & $16.26 \%$ & 0.185 \\
\hline $11-12$ & $45 / 183$ & $24.59 \%$ & $27 / 92$ & $29.35 \%$ & $18 / 91$ & $19.78 \%$ & 0.133 \\
\hline $13-14$ & $64 / 279$ & $22.94 \%$ & $49 / 159$ & $30.82 \%$ & $15 / 120$ & $12.50 \%$ & $<0.001$ \\
\hline $15-16$ & $90 / 354$ & $25.42 \%$ & $52 / 178$ & $29.21 \%$ & $38 / 176$ & $2.59 \%$ & 0.1 \\
\hline $17-18$ & $51 / 206$ & $24.76 \%$ & $22 / 75$ & $29.33 \%$ & $29 / 131$ & $22.14 \%$ & 0.25 \\
\hline Grade level & & & & & & & \\
\hline Elementary school students & $91 / 395$ & $23.04 \%$ & $56 / 194$ & $28.87 \%$ & $35 / 201$ & $17.41 \%$ & 0.007 \\
\hline Middle school students & $107 / 427$ & $25.06 \%$ & $70 / 218$ & $32.11 \%$ & $37 / 209$ & $17.70 \%$ & 0.001 \\
\hline High school students & $112 / 479$ & $23.38 \%$ & $56 / 213$ & $26.29 \%$ & $56 / 266$ & $21.05 \%$ & 0.178 \\
\hline P value: comparison between boys and girls. & & & & & \\
\hline
\end{tabular}




\begin{tabular}{|c|c|c|c|c|c|}
\hline & & & non-MAFLD & MAFLD & $\begin{array}{l}P \\
\text { value }\end{array}$ \\
\hline \multirow{4}{*}{$\begin{array}{l}\text { Basic information of } \\
\text { children }\end{array}$} & $\mathrm{n}$ & & 52 & 12 & \\
\hline & Gender(boys/girls) & & $20 / 32$ & $11 / 1$ & 0.001 \\
\hline & Age(years) & & $11.77 \pm 0.43$ & $11.83 \pm 0.39$ & 0.635 \\
\hline & $B M I(k g / m 2)$ & & $18.29 \pm 3.26$ & $27.82 \pm 3.15$ & $<.001$ \\
\hline \multirow[t]{6}{*}{ Parental situation } & BMI of father $\left(\mathrm{kg} / \mathrm{m}^{2}\right)$ & & $24.15 \pm 3.79$ & $25.16 \pm 2.15$ & 0.442 \\
\hline & BMI of mother $\left(\mathrm{kg} / \mathrm{m}^{2}\right)$ & & $22.66 \pm 3.81$ & $25.76 \pm 2.59$ & 0.017 \\
\hline & Education background (father) & $\begin{array}{l}\text { High school and } \\
\text { below }\end{array}$ & $14 / 50(28 \%)$ & $7 / 12(58.33 \%)$ & 0.046 \\
\hline & & $\begin{array}{l}\text { undergraduate and } \\
\text { above }\end{array}$ & $36 / 50(72 \%)$ & $5 / 12(41.67 \%)$ & \\
\hline & Education background (mather) & $\begin{array}{l}\text { High school and } \\
\text { below }\end{array}$ & 24/51(47.06\%) & $7 / 12(58.33 \%)$ & 0.482 \\
\hline & & $\begin{array}{l}\text { undergraduate and } \\
\text { above }\end{array}$ & $27 / 51(52.94 \%)$ & $5 / 12(41.67 \%)$ & \\
\hline \multirow{3}{*}{$\begin{array}{l}\text { The situation of birth } \\
\text { (children) }\end{array}$} & Weight(kg) & & $3.50 \pm 0.77$ & $4.08 \pm 0.78$ & 0.056 \\
\hline & Breast milk & Yes & $42 / 46(91.30 \%)$ & $11 / 11(100 \%)$ & 0.310 \\
\hline & & No & $4 / 46(8.70 \%)$ & 0 & \\
\hline \multirow[t]{12}{*}{ Movement of children } & Sports & Like & 18/52(34.62\%) & 4/12(33.33\%) & 0.933 \\
\hline & & Dislike & $34 / 52(65.38 \%)$ & $8 / 12(66.67 \%)$ & \\
\hline & The frequnce of doing sports & Every day & 29/52(55.77\%) & $5 / 12(41.67 \%)$ & 0.378 \\
\hline & & $1-6$ days a week & $20 / 52(38.46 \%)$ & $3 / 12(25 \%)$ & 0.381 \\
\hline & & Never & $3 / 52(5.77 \%)$ & 4/12(33.33\%) & 0.006 \\
\hline & The time of sports every day & Less than 30 min & $31 / 52(59.62 \%)$ & 4/12(33.33\%) & 0.099 \\
\hline & & More than $30 \mathrm{~min}$ & $21 / 52(40.38 \%)$ & $8 / 12(66.67 \%)$ & \\
\hline & Intensity of doing sports & Light exercise & $10 / 50(20 \%)$ & $2 / 12(16.67 \%)$ & 0.793 \\
\hline & & Moderate exercise & $24 / 50(48 \%)$ & $5 / 12(41.67 \%)$ & 0.693 \\
\hline & & Intense exercise & $16 / 50(32 \%)$ & $5 / 12(41.67 \%)$ & 0.525 \\
\hline & Sports grade & Good & $44 / 44(100 \%)$ & 9/10(90\%) & 0.034 \\
\hline & & Bad & 0 & $1 / 10(10 \%)$ & \\
\hline \multirow{3}{*}{$\begin{array}{l}\text { Entertainment and rest } \\
\text { of children }\end{array}$} & The time of sleeping every day(h) & & $7.44 \pm 1.87$ & $8.36 \pm 1.21$ & 0.122 \\
\hline & the time of static activity every day(h) & & $8.84 \pm 5.76$ & $11.44 \pm 3.97$ & 0.120 \\
\hline & The time of dynamic activity every day(h) & & $3.23 \pm 3.72$ & $2.81 \pm 3.16$ & 0.770 \\
\hline \multirow[t]{4}{*}{ Diet of children } & The frequence of eating fruit & $\begin{array}{l}\text { More than once a } \\
\text { day }\end{array}$ & $45 / 52(86.54 \%)$ & 10/12(83.33\%) & 0.773 \\
\hline & & $\begin{array}{l}\text { Less than once a } \\
\text { day }\end{array}$ & $7 / 52(13.46 \%)$ & $2 / 12(16.67 \%)$ & \\
\hline & Kinds of fruits everyday if eating everyday & & $2.49 \pm 1.12$ & $3.55 \pm 1.92$ & 0.105 \\
\hline & $\begin{array}{l}\text { Kinds of fruits a week if not eating } \\
\text { everyday? }\end{array}$ & & $4.46 \pm 2.39$ & $3.80 \pm 1.93$ & 0.431 \\
\hline
\end{tabular}




\begin{tabular}{|c|c|c|c|c|c|}
\hline & & & non-MAFLD & MAFLD & $\begin{array}{l}P \\
\text { value }\end{array}$ \\
\hline & The frequence of eating vegetable & $\begin{array}{l}\text { More than once a } \\
\text { day }\end{array}$ & $48 / 52(92.31 \%)$ & $11 / 12(91.67 \%)$ & 0.941 \\
\hline & & $\begin{array}{l}\text { Less than once a } \\
\text { day }\end{array}$ & $4 / 52(7.69 \%)$ & $1 / 12(8.33 \%)$ & \\
\hline & $\begin{array}{l}\text { Kinds of vegetable everyday if eating } \\
\text { everyday }\end{array}$ & & $3.11 \pm 1.63$ & $4.20 \pm 2.30$ & 0.080 \\
\hline & $\begin{array}{l}\text { Kinds of vegetable a week if you not eating } \\
\text { everyday }\end{array}$ & & $4.97 \pm 2.53$ & $4.11 \pm 1.90$ & 0.351 \\
\hline & $\begin{array}{l}\text { The frequnce of drinking sweet beverage a } \\
\text { week }\end{array}$ & $\begin{array}{l}\text { More than once a } \\
\text { week }\end{array}$ & $26 / 52(50 \%)$ & $9 / 12(75 \%)$ & 0.117 \\
\hline & & $\begin{array}{l}\text { Less than once a } \\
\text { week }\end{array}$ & $26 / 52(50 \%)$ & $3 / 12(25 \%)$ & \\
\hline & $\begin{array}{l}\text { Times of drinking sweet beverage every day } \\
\text { if drinking every day }\end{array}$ & & $0.47 \pm 0.56$ & $0.75 \pm 1.04$ & 0.301 \\
\hline & The frequnce of eating sweet food & $\begin{array}{l}\text { More than once a } \\
\text { week }\end{array}$ & $38 / 50(76 \%)$ & $7 / 12(58.33 \%)$ & 0.218 \\
\hline & & $\begin{array}{l}\text { Less than once a } \\
\text { week }\end{array}$ & $12 / 50(24 \%)$ & $5 / 12(41.67 \%)$ & \\
\hline & The frequence of eating breakfast & Every day & $41 / 51(80.39 \%)$ & 10/12(83.33\%) & 0.815 \\
\hline & & 2-6 days a week & $8 / 51(15.69 \%)$ & $0 / 12$ & 0.142 \\
\hline & & 1 day a week & 0 & 1/12(8.33\%) & 0.038 \\
\hline & & $\begin{array}{l}\text { Not eating or long } \\
\text { time }\end{array}$ & $2 / 51(3.92 \%)$ & $1 / 12(8.33 \%)$ & 0.518 \\
\hline & The frequence of eating snacks & Every day & $1 / 50(2 \%)$ & $2 / 12(16.67 \%)$ & 0.033 \\
\hline & & $1-6$ days a week & $42 / 50(84 \%)$ & 10/12(83.33\%) & 0.955 \\
\hline & & Never & $7 / 50(14 \%)$ & 0 & 0.169 \\
\hline & $\begin{array}{l}\text { The frequence of eating carefully and } \\
\text { slowly }\end{array}$ & Always & $49 / 52(94.23 \%)$ & $8 / 12(66.67 \%)$ & 0.006 \\
\hline & & Never & $3 / 52(5.77 \%)$ & 4/12(33.33\%) & \\
\hline & Picky eaters & No & $38 / 47(80.85 \%)$ & $11 / 12(91.67 \%)$ & 0.373 \\
\hline & & Yes & 9/47(19.15\%) & $1 / 12(8.33 \%)$ & \\
\hline & The frequence of eating fast food & $\begin{array}{l}\text { More than three } \\
\text { times a week }\end{array}$ & 0 & $1 / 12(8.33 \%)$ & 0.036 \\
\hline & & $\begin{array}{l}\text { Less than three } \\
\text { times a week }\end{array}$ & $52 / 52(100 \%)$ & $11 / 12(91.67 \%)$ & \\
\hline & The frequence of eating fried food & $\begin{array}{l}\text { More than three } \\
\text { times a week }\end{array}$ & $7 / 52(13.46 \%)$ & $3 / 12(25 \%)$ & 0.321 \\
\hline & & $\begin{array}{l}\text { Less than three } \\
\text { times a week }\end{array}$ & $45 / 52(86.54 \%)$ & $9 / 12(75 \%)$ & \\
\hline Learning condition of & The time in class(studying) & & $8.91 \pm 2.72$ & $9.60 \pm 1.78$ & 0.456 \\
\hline & The time out of class(studying) & & $2.77 \pm 1.79$ & $4.00 \pm 2.21$ & 0.064 \\
\hline & Study stress & Yes & $44 / 52(84.62 \%)$ & 10/12(83.33\%) & 0.912 \\
\hline & & No & $8 / 52(15.38 \%)$ & $2 / 12(16.67 \%)$ & \\
\hline $\begin{array}{l}\text { The situation of } \\
\text { parental awareness }\end{array}$ & $\begin{array}{l}\text { Do parents hope that children should be } \\
\text { fat? }\end{array}$ & Fat & $4 / 52(7.69 \%)$ & $1 / 12(8.33 \%)$ & 0.941 \\
\hline & & Neither fat nor thin & $44 / 52(84.62 \%)$ & $7 / 12(58.33 \%)$ & 0.041 \\
\hline
\end{tabular}




\begin{tabular}{|c|c|c|c|c|}
\hline & & non-MAFLD & MAFLD & $\begin{array}{l}P \\
\text { value }\end{array}$ \\
\hline & Thin & $4 / 52(7.69 \%)$ & 4/12(33.33\%) & $\dot{0} 0.001$ \\
\hline $\begin{array}{l}\text { Does community have information on } \\
\text { nutrition and health? }\end{array}$ & Yes & $41 / 50(82 \%)$ & 8/11(72.73\%) & 0.484 \\
\hline & No & $9 / 50(18 \%)$ & $3 / 11(27.27 \%)$ & \\
\hline
\end{tabular}




\begin{tabular}{|c|c|c|c|c|c|}
\hline & & & non-MAFLD & MAFLD & $\begin{array}{l}P \\
\text { value }\end{array}$ \\
\hline \multirow{4}{*}{$\begin{array}{l}\text { Basic information of } \\
\text { children }\end{array}$} & $\mathrm{n}$ & & 45 & 8 & \\
\hline & Gender(boys/girls) & & $27 / 18$ & $5 / 3$ & 0.894 \\
\hline & Age(years) & & $15.64 \pm 1.58$ & $15.38 \pm 1.51$ & 0.657 \\
\hline & $B M I(k g / m 2)$ & & $19.47 \pm 2.19$ & $27.60 \pm 2.82$ & $\begin{array}{l}<.001 \\
0.001\end{array}$ \\
\hline \multirow[t]{6}{*}{ Parental situation } & BMI of father $\left(\mathrm{kg} / \mathrm{m}^{2}\right)$ & & $22.47 \pm 2.88$ & $25.18 \pm 3.86$ & 0.032 \\
\hline & BMI of mother $\left(\mathrm{kg} / \mathrm{m}^{2}\right)$ & & $21.25 \pm 2.22$ & $24.54 \pm 3.67$ & 0.002 \\
\hline & Education background (father) & $\begin{array}{l}\text { High school and } \\
\text { below }\end{array}$ & $18 / 45(40 \%)$ & $7 / 8(87.5 \%)$ & 0.013 \\
\hline & & $\begin{array}{l}\text { undergraduate and } \\
\text { above }\end{array}$ & $27 / 45(60 \%)$ & $1 / 8(12.5 \%)$ & \\
\hline & Education background (mather) & $\begin{array}{l}\text { High school and } \\
\text { below }\end{array}$ & $21 / 45(46.67 \%)$ & $6 / 8(75 \%)$ & 0.140 \\
\hline & & $\begin{array}{l}\text { undergraduate and } \\
\text { above }\end{array}$ & $24 / 45(53.33 \%)$ & $2 / 8(25 \%)$ & \\
\hline \multirow{3}{*}{$\begin{array}{l}\text { The situation of birth } \\
\text { (children) }\end{array}$} & Weight (kg) & & $3.86 \pm 0.84$ & $3.61 \pm 1.10$ & 0.461 \\
\hline & Breast milk & Yes & $43 / 45(95.56 \%)$ & $7 / 7(100 \%)$ & 0.569 \\
\hline & & No & $2 / 45(4.44 \%)$ & 0 & \\
\hline \multirow[t]{12}{*}{ Movement of children } & Sports & Like & $13 / 45(28.89 \%)$ & $5 / 8(62.5 \%)$ & 0.064 \\
\hline & & Dislike & $32 / 45(71.11 \%)$ & $3 / 8(37.5 \%)$ & \\
\hline & The frequnce of doing sports & Every day & $25 / 45(55.56 \%)$ & $1 / 8(12.5 \%)$ & 0.285 \\
\hline & & $1-6$ days a week & 15/45(33.33\%) & $5 / 8(62.5 \%)$ & 0.025 \\
\hline & & Never & $5 / 45(11.11 \%)$ & $2 / 8(25 \%)$ & 0.285 \\
\hline & The time of sports every day & Less than 30 min & $25 / 45(55.56 \%)$ & $7 / 8(75 \%)$ & 0.089 \\
\hline & & More than $30 \mathrm{~min}$ & $20 / 45(44.44 \%)$ & $1 / 8(25 \%)$ & \\
\hline & Intensity of doing sports & Light exercise & $17 / 44(38.67 \%)$ & $5 / 8(62.5 \%)$ & 0.209 \\
\hline & & Moderate exercise & $12 / 44(27.27 \%)$ & 0 & 0.092 \\
\hline & & Intense exercise & $15 / 44(34.09 \%)$ & $3 / 8(37.50 \%)$ & 0.852 \\
\hline & Sports grade & Good & $37 / 42(88.10 \%)$ & $3 / 8(37.5 \%)$ & 0.001 \\
\hline & & Bad & $5 / 42(11.90 \%)$ & $5 / 8(62.5 \%)$ & \\
\hline \multirow{3}{*}{$\begin{array}{l}\text { Entertainment and rest } \\
\text { of children }\end{array}$} & The time of sleeping every day(h) & & $6.97 \pm 1.91$ & $8.13 \pm 3.18$ & 0.163 \\
\hline & the time of static activity every day(h) & & $10.94 \pm 6.60$ & $7.43 \pm 5.77$ & 0.190 \\
\hline & The time of dynamic activity every day(h) & & $2.05 \pm 1.56$ & $3.17 \pm 1.84$ & 0.116 \\
\hline \multirow[t]{4}{*}{ Diet of children } & The frequence of eating fruit & $\begin{array}{l}\text { More than once a } \\
\text { day }\end{array}$ & $33 / 44(75 \%)$ & $6 / 8(75 \%)$ & 1.000 \\
\hline & & $\begin{array}{l}\text { Less than once a } \\
\text { day }\end{array}$ & $11 / 44(25 \%)$ & $2 / 12(25 \%)$ & \\
\hline & Kinds of fruits everyday if eating everyday & & $2.27 \pm 1.17$ & $2.25 \pm 1.04$ & 0.959 \\
\hline & Kinds of fruits a week if not eating everyday? & & $3.67 \pm 1.43$ & $4.29 \pm 2.56$ & 0.376 \\
\hline
\end{tabular}




\begin{tabular}{|c|c|c|c|c|c|}
\hline & & & non-MAFLD & MAFLD & $\begin{array}{l}P \\
\text { value }\end{array}$ \\
\hline & The frequence of eating vegetable & $\begin{array}{l}\text { More than once a } \\
\text { day }\end{array}$ & $38 / 45(84.44 \%)$ & $8 / 8(100 \%)$ & 0.231 \\
\hline & & $\begin{array}{l}\text { Less than once a } \\
\text { day }\end{array}$ & $7 / 45(15.56 \%)$ & 0 & \\
\hline & $\begin{array}{l}\text { Kinds of vegetable everyday if eating } \\
\text { everyday }\end{array}$ & & $2.67 \pm 1.71$ & $2.25 \pm 0.71$ & 0.503 \\
\hline & $\begin{array}{l}\text { Kinds of vegetable a week if you not eating } \\
\text { everyday }\end{array}$ & & $4.47 \pm 2.70$ & $3.29 \pm 0.76$ & 0.261 \\
\hline & $\begin{array}{l}\text { The frequnce of drinking sweet beverage a } \\
\text { week }\end{array}$ & $\begin{array}{l}\text { More than once a } \\
\text { week }\end{array}$ & $34 / 45(75.56 \%)$ & $7 / 8(87.5 \%)$ & 0.457 \\
\hline & & $\begin{array}{l}\text { Less than once a } \\
\text { week }\end{array}$ & $11 / 45(24.44 \%)$ & $1 / 8(12.50 \%)$ & \\
\hline & $\begin{array}{l}\text { Times of drinking sweet beverage every day } \\
\text { if drinking every day }\end{array}$ & & $1.00 \pm 0.92$ & $0.57 \pm 0.54$ & 0.244 \\
\hline & The frequnce of eating sweet food & $\begin{array}{l}\text { More than once a } \\
\text { week }\end{array}$ & $36 / 45(80 \%)$ & $8 / 8(100 \%)$ & 0.165 \\
\hline & & $\begin{array}{l}\text { Less than once a } \\
\text { week }\end{array}$ & $9 / 45(20 \%)$ & 0 & \\
\hline & The frequence of eating breakfast & Every day & $36 / 44(81.82 \%)$ & $4 / 8(50 \%)$ & 0.049 \\
\hline & & 2-6 days a week & $8 / 44(18.18 \%)$ & $2 / 8(25 \%)$ & 0.653 \\
\hline & & 1 day a week & 0 & $1 / 8(12.50 \%)$ & 0.018 \\
\hline & & $\begin{array}{l}\text { Not eating or long } \\
\text { time }\end{array}$ & 0 & $1 / 8(12.50 \%)$ & 0.018 \\
\hline & The frequence of eating snacks & Every day & $6 / 45(13.33 \%)$ & $1 / 8(12.50 \%)$ & 0.949 \\
\hline & & $1-6$ days a week & $31 / 45(68.89 \%)$ & $7 / 8(87.5 \%)$ & 0.282 \\
\hline & & Never & $8 / 45(17.78 \%)$ & 0 & 0.196 \\
\hline & The frequence of eating carefully and slowly & Always & $42 / 45(93.33 \%)$ & $7 / 8(87.5 \%)$ & 0.565 \\
\hline & & Never & $3 / 45(6.66 \%)$ & $1 / 8(12.50 \%)$ & \\
\hline & Picky eaters & No & $29 / 41(70.73 \%)$ & $3 / 7(42.86 \%)$ & 0.148 \\
\hline & & Yes & $12 / 41(29.27 \%)$ & $4 / 7(57.14 \%)$ & \\
\hline & The frequence of eating fast food & $\begin{array}{l}\text { More than three } \\
\text { times a week }\end{array}$ & $14 / 45(31.11 \%)$ & $2 / 8(25 \%)$ & 0.729 \\
\hline & & $\begin{array}{l}\text { Less than three } \\
\text { times a week }\end{array}$ & $31 / 45(68.89 \%)$ & $6 / 8(75 \%)$ & \\
\hline & The frequence of eating fried food & $\begin{array}{l}\text { More than three } \\
\text { times a week }\end{array}$ & $12 / 45(26.67 \%)$ & $2 / 8(25 \%)$ & 0.922 \\
\hline & & $\begin{array}{l}\text { Less than three } \\
\text { times a week }\end{array}$ & $33 / 45(73.33 \%)$ & $6 / 8(75 \%)$ & \\
\hline Learning condition of & The time in class(studying) & & $10.80 \pm 3.13$ & $9.86 \pm 3.34$ & 0.467 \\
\hline & The time out of class(studying) & & $2.93 \pm 1.76$ & $2.71 \pm 1.70$ & 0.766 \\
\hline & Study stress & Yes & $40 / 44(90.91 \%)$ & $7 / 7(100 \%)$ & 0.406 \\
\hline & & No & $4 / 44(9.09 \%)$ & 0 & \\
\hline $\begin{array}{l}\text { The situation of parental } \\
\text { awareness }\end{array}$ & Do parents hope that children should be fat? & Fat & $4 / 45(8.89 \%)$ & $2 / 8(25 \%)$ & 0.185 \\
\hline & & Neither fat nor thin & $31 / 45(68.89 \%)$ & $5 / 8(62.5 \%)$ & 0.721 \\
\hline & & Thin & $10 / 45(22.22 \%)$ & $1 / 8(12.50 \%)$ & 0.532 \\
\hline
\end{tabular}




\begin{tabular}{|c|c|c|c|c|}
\hline & & non-MAFLD & MAFLD & $\begin{array}{l}P \\
\text { value }\end{array}$ \\
\hline $\begin{array}{l}\text { Does community have information on } \\
\text { nutrition and health? }\end{array}$ & Yes & $35 / 44(79.55 \%)$ & $3 / 8(37.5 \%)$ & 0.014 \\
\hline & No & 9/44(20.45\%) & $5 / 8(62.5 \%)$ & \\
\hline
\end{tabular}




\begin{tabular}{|c|c|c|c|c|c|}
\hline & & & Boys & Girls & $\begin{array}{l}P \\
\text { value }\end{array}$ \\
\hline \multirow{3}{*}{$\begin{array}{l}\text { Basic information of } \\
\text { children }\end{array}$} & $\mathrm{n}$ & & 63 & 54 & \\
\hline & Age(years) & & $13.73 \pm 2.27$ & $13.26 \pm 2.11$ & 0.25 \\
\hline & $B M I(k g / m 2)$ & & $21.31 \pm 4.46$ & $19.24 \pm 4.13$ & 0.011 \\
\hline \multirow[t]{6}{*}{ Parental situation } & BMI of father $\left(\mathrm{kg} / \mathrm{m}^{2}\right)$ & & $23.84 \pm 2.95$ & $23.33 \pm 3.97$ & 0.452 \\
\hline & BMI of mother $\left(\mathrm{kg} / \mathrm{m}^{2}\right)$ & & $22.82 \pm 3.49$ & $22.10 \pm 3.25$ & 0.265 \\
\hline & Education background (father) & $\begin{array}{l}\text { High school and } \\
\text { below }\end{array}$ & $25 / 62(40.32 \%)$ & $21 / 53(39.62 \%)$ & 0.939 \\
\hline & & $\begin{array}{l}\text { undergraduate and } \\
\text { above }\end{array}$ & $37 / 62(59.68 \%)$ & $32 / 53(60.38 \%)$ & \\
\hline & Education background (mather) & $\begin{array}{l}\text { High school and } \\
\text { below }\end{array}$ & $27 / 63(42.86 \%)$ & $17 / 53(32.08 \%)$ & 0.233 \\
\hline & & $\begin{array}{l}\text { undergraduate and } \\
\text { above }\end{array}$ & $36 / 63(57.14 \%)$ & $36 / 53(67.92 \%)$ & \\
\hline \multirow{5}{*}{$\begin{array}{l}\text { The situation of birth } \\
\text { (children) }\end{array}$} & Weight (kg) & & $3.71 \pm 0.88$ & $3.70 \pm 0.79$ & 0.941 \\
\hline & Breast milk & Yes & $55 / 58(94.8 \%)$ & 48/51(94.1\%) & 0.871 \\
\hline & & No & $3 / 58(5.2 \%)$ & $3 / 51(5.9 \%)$ & \\
\hline & $\begin{array}{l}\text { whether breast milk was exclusively consumed } \\
\text { in the first four months after birth }\end{array}$ & Yes & $33 / 58(56.9 \%)$ & $36 / 47(76.6 \%)$ & 0.034 \\
\hline & & No & 25/58(43.1\%) & $11 / 47(23.4 \%)$ & \\
\hline \multirow{12}{*}{$\begin{array}{l}\text { Movement of } \\
\text { children }\end{array}$} & Sports & Like & $13 / 63(20.63 \%)$ & $27 / 54(50 \%)$ & 0.001 \\
\hline & & Dislike & $50 / 63(79.37 \%)$ & $27 / 54(50 \%)$ & \\
\hline & The frequnce of doing sports & Every day & $37 / 63(58.73 \%)$ & $15 / 54(27.78 \%)$ & 0.001 \\
\hline & & $1-6$ days a week & $18 / 63(28.57 \%)$ & $33 / 54(61.11 \%)$ & $<.001$ \\
\hline & & Never & $8 / 63(12.7 \%)$ & $6 / 54(11 / 1 \%)$ & 0.792 \\
\hline & The time of sports every day & Less than $30 \mathrm{~min}$ & $28 / 63(44.44 \%)$ & $39 / 54(72.22 \%)$ & 0.002 \\
\hline & & More than $30 \mathrm{~min}$ & $35 / 63(55.56 \%)$ & $15 / 54(27.78 \%)$ & \\
\hline & Intensity of doing sports & Light exercise & $19 / 62(30.6 \%)$ & $15 / 52(28.8 \%)$ & $<.001$ \\
\hline & & Moderate exercise & $11 / 62(17.7 \%)$ & $30 / 52(57.7 \%)$ & \\
\hline & & Intense exercise & $32 / 62(51.6 \%)$ & $7 / 52(13.5 \%)$ & \\
\hline & Sports grade & Good & $43 / 55(78.18 \%)$ & $40 / 49(81.63 \%)$ & 0.662 \\
\hline & & Bad & $12 / 55(21.82 \%)$ & $9 / 49(18.37 \%)$ & \\
\hline \multirow{3}{*}{$\begin{array}{l}\text { Entertainment and } \\
\text { rest of children }\end{array}$} & The time of sleeping every day(h) & & $7.87 \pm 2.07$ & $6.87 \pm 1.73$ & 0.006 \\
\hline & the time of static activity every day(h) & & $9.59 \pm 6.17$ & $10.16 \pm 6.00$ & 0.638 \\
\hline & The time of dynamic activity every day(h) & & $2.69 \pm 2.96$ & $2.67 \pm 2.73$ & 0.965 \\
\hline \multirow[t]{2}{*}{ Diet of children } & The frequence of eating fruit & $\begin{array}{l}\text { More than once a } \\
\text { day }\end{array}$ & $52 / 63(82.54 \%)$ & $45 / 53(84.91 \%)$ & 0.732 \\
\hline & & $\begin{array}{l}\text { Less than once a } \\
\text { day }\end{array}$ & $11 / 63(17.46 \%)$ & $8 / 53(15.09 \%)$ & \\
\hline
\end{tabular}




\begin{tabular}{|c|c|c|c|c|c|}
\hline & & & Boys & Girls & $\begin{array}{l}P \\
\text { value }\end{array}$ \\
\hline & \multicolumn{2}{|l|}{ Kinds of fruits everyday if eating everyday } & $2.67 \pm 1.45$ & $2.28 \pm 0.99$ & 0.112 \\
\hline & \multicolumn{2}{|l|}{ Kinds of fruits a week if not eating everyday? } & $3.91 \pm 1.91$ & $4.24 \pm 2.17$ & 0.470 \\
\hline & The frequence of eating vegetable & $\begin{array}{l}\text { More than once a } \\
\text { day }\end{array}$ & $56 / 63(88.89 \%)$ & $49 / 54(90.74 \%)$ & 0.742 \\
\hline & & $\begin{array}{l}\text { Less than once a } \\
\text { day }\end{array}$ & $7 / 63(11.11 \%)$ & $5 / 54(9.26 \%)$ & \\
\hline & \multicolumn{2}{|l|}{ Kinds of vegetable everyday if eating everyday } & $3.05 \pm 1.79$ & $2.88 \pm 1.67$ & 0.609 \\
\hline & \multicolumn{2}{|l|}{$\begin{array}{l}\text { Kinds of vegetable a week if you not eating } \\
\text { everyday }\end{array}$} & $4.42 \pm 2.21$ & $4.66 \pm 2.75$ & 0.667 \\
\hline & \multirow[t]{2}{*}{ The frequnce of drinking sweet beverage a week } & $\begin{array}{l}\text { More than once a } \\
\text { week }\end{array}$ & 49/63(77.78\%) & $27 / 54(50 \%)$ & 0.002 \\
\hline & & $\begin{array}{l}\text { Less than once a } \\
\text { week }\end{array}$ & $14 / 63(22.2 \%)$ & $27 / 54(50 \%)$ & \\
\hline & \multicolumn{2}{|l|}{$\begin{array}{l}\text { Times of drinking sweet beverage every day if } \\
\text { drinking every day }\end{array}$} & $0.73 \pm 0.87$ & $0.73 \pm 0.72$ & 0.992 \\
\hline & \multirow[t]{2}{*}{ The frequnce of eating sweet food } & $\begin{array}{l}\text { More than once a } \\
\text { week }\end{array}$ & $49 / 61(80.33 \%)$ & $40 / 54(74.07 \%)$ & 0.424 \\
\hline & & $\begin{array}{l}\text { Less than once a } \\
\text { week }\end{array}$ & $12 / 61(19.7 \%)$ & $14 / 54(25.9 \%)$ & \\
\hline & \multirow[t]{4}{*}{ The frequence of eating breakfast } & Every day & $55 / 63(87.3 \%)$ & $36 / 52(69.2 \%)$ & 0.018 \\
\hline & & $2-6$ days a week & $6 / 63(9.52 \%)$ & $14 / 52(26.92 \%)$ & 0.014 \\
\hline & & 1 day a week & $1 / 63(1.6 \%)$ & $0 / 52$ & 0.362 \\
\hline & & $\begin{array}{l}\text { Not eating or long } \\
\text { time }\end{array}$ & $1 / 63(1.6 \%)$ & $2 / 52(3.8 \%)$ & 0.449 \\
\hline & \multirow[t]{3}{*}{ The frequence of eating snacks } & Every day & $8 / 62(12.9 \%)$ & $2 / 53(3.8 \%)$ & 0.083 \\
\hline & & $1-6$ days a week & $45 / 62(72.58 \%)$ & $45 / 53(84.91 \%)$ & 0.110 \\
\hline & & Never & $9 / 62(14.5 \%)$ & $6 / 53(11.3 \%)$ & 0.612 \\
\hline & \multirow[t]{2}{*}{ The frequence of eating carefully and slowly } & Always & $56 / 63(88.9 \%)$ & $50 / 54(92.59 \%)$ & 0.494 \\
\hline & & Never & $7 / 63(11.1 \%)$ & $4 / 54(7.4 \%)$ & \\
\hline & \multirow[t]{2}{*}{ Picky eaters } & No & $46 / 57(80.7 \%)$ & $35 / 50(70.0 \%)$ & 0.198 \\
\hline & & Yes & $11 / 57(19.3 \%)$ & $15 / 50(30.0 \%)$ & \\
\hline & \multirow[t]{2}{*}{ The frequence of eating fast food } & $\begin{array}{l}\text { More than three } \\
\text { times a week }\end{array}$ & $5 / 63(7.94 \%)$ & $2 / 54(3.7 \%)$ & 0.336 \\
\hline & & $\begin{array}{l}\text { Less than three } \\
\text { times a week }\end{array}$ & $58 / 63(92.06 \%)$ & $52 / 54(96.3 \%)$ & \\
\hline & \multirow[t]{2}{*}{ The frequence of eating fried food } & $\begin{array}{l}\text { More than three } \\
\text { times a week }\end{array}$ & 21/63(33.33\%) & $5 / 54(9.26 \%)$ & 0.002 \\
\hline & & $\begin{array}{l}\text { Less than three } \\
\text { times a week }\end{array}$ & $42 / 63(66.67 \%)$ & $49 / 54(90.74 \%)$ & \\
\hline \multirow{4}{*}{$\begin{array}{l}\text { Learning condition } \\
\text { of children }\end{array}$} & \multicolumn{2}{|l|}{ The time in class(studying) } & $10.39 \pm 3.32$ & $9.47 \pm 3.17$ & 0.16 \\
\hline & \multicolumn{2}{|l|}{ The time out of class(studying) } & $2.98 \pm 1.86$ & $2.98 \pm 1.79$ & 0.99 \\
\hline & \multirow[t]{2}{*}{ Study stress } & Yes & $54 / 61(88.52 \%)$ & $47 / 54(87.04 \%)$ & 0.808 \\
\hline & & No & 7/61(11.5\%) & 7/54(13.0\%) & \\
\hline
\end{tabular}

Due to technical limitations, tables 1, 2, 5, and 7 are only available as a download in the Supplemental Files section. 
Figures

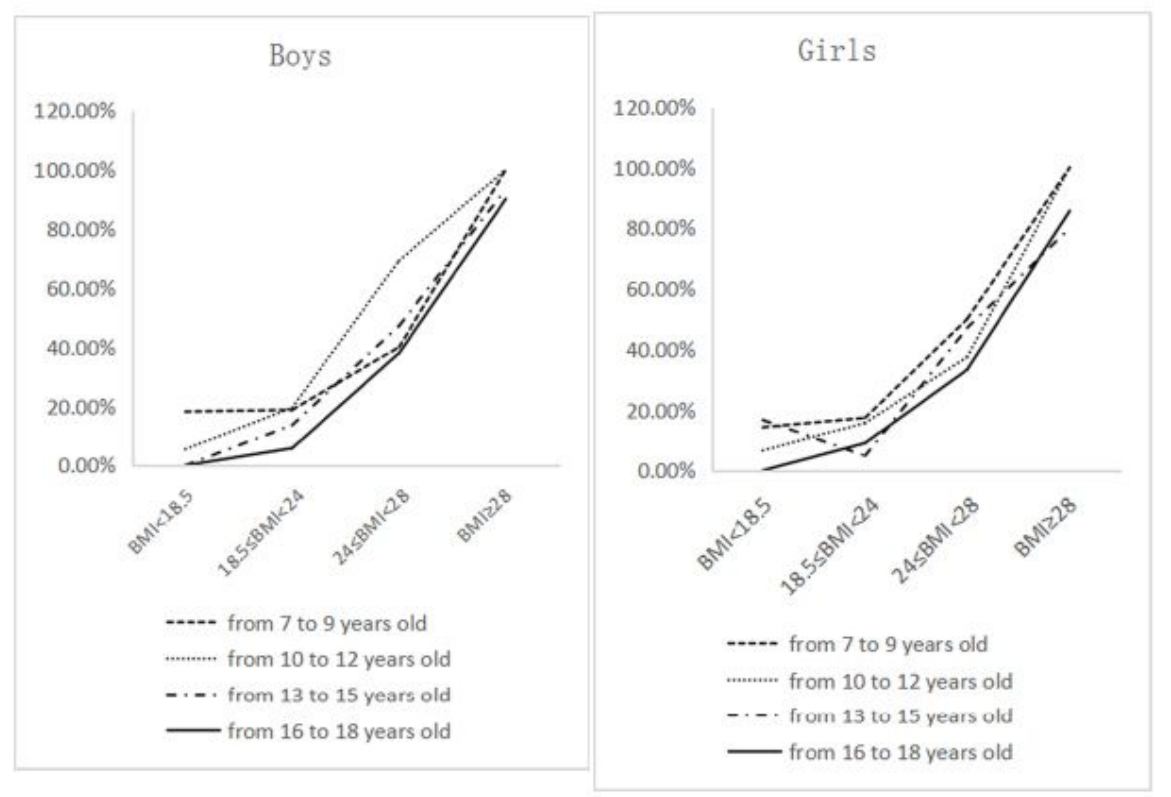

\section{Figure 1}

Prevalence of MAFLD in boys and girls under the delamination of age and BMI. The vertical axis of the graph represents the prevalence. BMI of the horizontal axis was divided into four stages. BMI=Body Mass Index.

\section{Supplementary Files}

This is a list of supplementary files associated with this preprint. Click to download.

- Table1.xlsx

- Table5.xIsx

- Table7.xIsx

- Table2.xIsx

- questionnaire.docx 